\title{
Article \\ Quality Control of Different Types of Honey and Propolis Collected from Romanian Accredited Beekeepers and Consumer's Risk Assessment
}

\author{
Magdalena Mititelu ${ }^{1,+}\left(\mathbb{D}\right.$, Denisa Ioana Udeanu ${ }^{1,+}\left(\mathbb{D}\right.$, Mirela Nedelescu ${ }^{2,3, * \mathbb{D}}$, Sorinel Marius Neacsu ${ }^{4,+}$, \\ Anca Cecilia Nicoara ${ }^{5,+}$, Eliza Oprea ${ }^{6, *(D)}$ and Manuela Ghica ${ }^{7}$
}

check for

updates

Citation: Mititelu, M.; Udeanu, D.I.; Nedelescu, M.; Neacsu, S.M.; Nicoara, A.C.; Oprea, E.; Ghica, M. Quality Control of Different Types of Honey and Propolis Collected from Romanian Accredited Beekeepers and Consumer's Risk Assessment. Crystals 2022, 12, 87. https:/ / doi.org/10.3390/ cryst12010087

Academic Editor: Venu Vangala

Received: 19 December 2021

Accepted: 6 January 2022

Published: 9 January 2022

Publisher's Note: MDPI stays neutral with regard to jurisdictional claims in published maps and institutional affiliations.

Copyright: (C) 2022 by the authors. Licensee MDPI, Basel, Switzerland. This article is an open access article distributed under the terms and conditions of the Creative Commons Attribution (CC BY) license (https:// creativecommons.org/licenses/by/ $4.0 /)$.
1 Department of Clinical Laboratory and Food Safety, Faculty of Pharmacy, University of Medicine and Pharmacy Carol Davila, 020956 Bucharest, Romania; magdalena.mititelu@umfcd.ro (M.M.); denisa.udeanu@umfcd.ro (D.I.U.)

2 Department of Hygiene and Environmental Health, Faculty of Medicine, University of Medicine and Pharmacy Carol Davila, 020956 Bucharest, Romania

3 Department of Food Hygiene and Nutrition, National Centre for Environmental Hazards Monitoring, National Institute of Public Health, 050463 Bucharest, Romania

4 Professional Farma Line, Prahova, 105200 Baicoi, Romania; sorinel.neacsu@pfarma.ro

5 Department of Pharmaceutical Technology and Biopharmacy, Faculty of Pharmacy, University of Medicine and Pharmacy Carol Davila, 020956 Bucharest, Romania; anca.nicoara@umfcd.ro

6 Department of Organic Chemistry, Biochemistry and Catalysis, Faculty of Chemistry, University of Bucharest, 030018 Bucharest, Romania

7 Department of Biostatistics, Faculty of Pharmacy, University of Medicine and Pharmacy Carol Davila, 020956 Bucharest, Romania; manuela.ghica@umfcd.ro

* Correspondence: mirela.nedelescu@umfcd.ro (M.N.); eliza.oprea@g.unibuc.ro (E.O.)

+ These authors contributed equally to this work.

\begin{abstract}
Honey is a natural product recognized and appreciated for its nutritional value and therapeutic potential. However, the quality of bee honey is essential because various contaminants can seriously affect consumers' health. In the experimental part of the work, we analyzed different types of honey (linden, black locust, rapeseed and multifloral honey) and propolis, which were collected from Romanian accredited beekeepers who placed beehives in two areas characterized by different industrial activity: area 1 (A1) is an area with intense industrial activity, with other industries existing nearby, including a refinery, while area 2 (A2) is entirely devoid of industrial activity, but with moderate agricultural activity. A total of 144 samples were collected, twelve samples for each variety of honey, propolis and soil, corresponding to each area analyzed. In addition, seven heavy metals and three pesticides were tested for in the samples collected. Finally, the correlation between the degree of contamination with soil pollutants and the contamination of the bee products harvested from the analyzed areas was studied. Cadmium, lead, copper, zinc and the sum of DDT metabolites exceeded the maximum allowable levels in honey samples, with differences between different types of honey.
\end{abstract}

Keywords: honey; propolis; heavy metals; pesticides; bioconcentration factor; estimated daily intake

\section{Introduction}

Honey is the sweet product produced from the nectar of flowers, the secretions of plants, or what is present on plant surfaces by honeybees. After collecting the raw materials, bees process it, enrich it with their own substances and in the end store it in the honeycomb cells. Depending on the raw material used by bees to produce honey, there are two major types of honey: floral and honeydew [1,2]. Both types have a complex chemical composition which sustains their use in therapeutics.

Honey, one of the oldest medicinal remedies, is still of interest to scientists. Over time, more pharmacological properties of honey have been discovered, including anti-ulcer, 
anti-inflammatory, antioxidant and tissue regeneration properties. However, one of the most studied actions of honey is the antibacterial one. For this, several factors have been discovered that can potentiate it, such as low water content, hydrogen peroxide, acidity, non-peroxide compounds and bee defensin-1. Moreover, organoleptic properties, such as color, can provide information about antimicrobial activity. Thus, brown honey types, such as Manuka honey and honeydew, have good inhibitory properties for many bacterial species, even on methicillin-resistant Staphylococcus aureus and Pseudomonas aeruginosa. Several groups of researchers have also shown that microbiological methods can be used to determine the antibacterial activity of honey [3-6].

In terms of composition, honey contains water, carbohydrates, pollen, minerals, enzymes, vitamins, pigments, aromatic compounds and acids [7,8].

Honey helps to clean wounds, stimulates tissue regeneration and reduces inflammation, and clinical studies have shown that honey dressings produce a faster healing of burns with a lower degree of contractures and scars. This action is due to the moderate acidity and low level of hydrogen peroxide release that lead to tissue repair. Additionally, the increased viscosity of honey leads to the formation of a protective barrier against infections [9-15].

Many factors have been shown to contribute to the antibacterial activity of honey, such as its high viscosity, mainly due to its high sugar concentration and low water content, which helps to provide a protective barrier to prevent infection. In addition, its mild acidity and hydrogen peroxide content have obvious antimicrobial effects [16-18].

The composition and therapeutic effects of honey are strongly influenced by the source used by bees. Consumers and the pharmaceutical industry use different varieties of honey with specific characteristics. In dermato-cosmetic and hygiene products, honey products are used in face creams, toothpaste, etc. Honey and propolis are also valuable ingredients in various pharmaceutical forms for internal use, such as in tinctures, syrups, suspensions, etc. In general, honey is an important source of antioxidants, minerals, carbohydrates and compounds with antimicrobial action.

Among the most common floral honeys present on the market are multifloral, rapeseed, linden and black locust, which have significant nutritional values. Honey is recommended as an auxiliary treatment for diseases, such as constipation, asthenia, infections, strengthening the immune system and exhaustion [19-23].

Propolis is a natural remedy that has been used since ancient times. The beneficial effects of propolis are mentioned in the writings of ancient Greek and Roman physicians. Today, propolis is recommended for its antibacterial, antifungal, antiviral, hepatoprotective and anti-inflammatory properties to increase the body's natural resistance to infections and as an adjuvant in treating gastroduodenal ulcers. In addition, propolis soothes some dermatitis caused by bacteria or fungi when applied externally. So far, more than 180 components of propolis have been identified, mainly polyphenols. The most important polyphenols are flavonoids, along with phenolic acids and esters, phenolic aldehydes, ketones, etc. [24-26].

The chemical composition of the honey type and propolis is highly variable and depends on the location where it is produced due to the high variability in soil composition and the quality of water and air, which impact the quality of the raw materials used by the bees.

Honey represents a source of income for producers and also a food source for private use in small family farms.

In bee feed, it is forbidden to use products with added drugs or products bought based on honey and unsterilized pollen, which contaminate bee families with spores and mycelium that cause diseases specific to bees. Artificial feeding is stopped 15 days before the start of a production harvest.

Honey is highly valued by nutritionists and health professionals. The quality of honey used by consumers is critical because, on the one hand, bee honey is one of the most frequently counterfeited natural products. On the other hand, the quality of the environment has a significant influence on the degree of its contamination with various 
toxic pollutants. Therefore, the installation of beehives in an industrial environment polluted with heavy metals (near polluting enterprises or near areas where polluting enterprises are built) must be avoided to prevent contamination. Disease prevention in organic beekeeping is based on breed selection, growth management practices, best quality food and appropriate housing in hygienic conditions. In the treatment of bees, it is forbidden to use allopathic veterinary drugs and those obtained via chemical synthesis. During the production period, the hives must be located in areas where bees have adequate water sources, nectar and pollen and with the lowest possible degree of pollution [27,28].

The examination of bee products - honey, wax, bees, pollen, etc. - can provide valuable data on the presence of pollutants in the environment. As honey is a product for human consumption, its contamination with various compounds is frequently studied [29-31].

Currently, with the intense anthropogenic impact on nature, it is imperative to control the metal content in food and in the environment because there are known cases of the toxification of people with heavy metal compounds. Moreover, once assimilated, some heavy metals and pesticides are difficult to remove from the human body and can cause serious health effects, such as neurodegenerative diseases, cardiovascular diseases and cancers at different locations [32-39].

More and more toxic chemicals are being used in agriculture for combating diseases and the pests of crop plants or those in the forest area. However, insecticides, regardless of their nature, ingestion, contact or respiration, are harmful when they penetrate the bee's body and cause a physiological imbalance in several fundamental biological processes [38,40-44].

The use of contaminated products has a negative impact on health when used both as a food and in pharmaceutical preparations.

Romania ranks third place in honey production in Europe, after Spain and Hungary, and is followed by Poland, Greece, Germany, France, Bulgaria, Portugal, Croatia, Italy and the Czech Republic. However, honey consumption in Romania is low, though it has increased in recent years, from $500 \mathrm{~g}$ per person per year in 2015 to $900 \mathrm{~g}$ in 2020 [45,46].

The objective of the research is to analyze potentially toxic contaminants (heavy metals and pesticides) in samples from different types of honey and propolis collected from Romanian accredited beekeepers to establish a correlation between the degree of environmental contamination and the accumulation of pollutants in bee products from hives placed in the analyzed areas and to assess possible risks to consumers.

\section{Materials and Methods}

\subsection{Sample Collection}

One hundred and forty-four samples were collected from different types of honey (linden, black locust, rapeseed and multifloral honey), propolis and soil from Romanian accredited beekeepers during summer 2021 from two areas with different degrees of pollution: area $\mathrm{A} 1$, an area with intense industrial activity being located near a refinery and area $\mathrm{A} 2$, an area without industrial activity and with a moderate agricultural activity.

The propolis samples were obtained using special collectors, from which they were removed via refrigeration and crushing. The amount of propolis obtained from a family of bees varied between 100 and $400 \mathrm{~g}$. Each sample of honey and propolis was placed in an airtight glass container, labeled and stored in a cool, dry place away from light until analysis. The soil samples were collected from the areas where the hives were placed, at a depth of $25 \mathrm{~cm}$, and were placed in airtight glass containers, labeled and stored in the same conditions.

Twelve samples of each type of honey, propolis and soil were taken from each investigated area. 


\subsection{Heavy Metals and Pesticides Detection}

\subsubsection{Heavy Metals Analysis}

Concentrations of seven heavy metals, including chromium $(\mathrm{Cr})$, cadmium $(\mathrm{Cd})$, zinc $(\mathrm{Zn})$, copper $(\mathrm{Cu})$, lead $(\mathrm{Pb})$, nickel $(\mathrm{Ni})$ and manganese $(\mathrm{Mn})$, were determined using a Shimadzu AA 6500 Atomic Absorption Spectrometer after nitric acid digestion [33,47]. An air/acetylene flame was used as the atomizing source, which was used for all elements. The fuel used was acetylene with a purity of $99.999 \%$, and the oxidizer was air.

The fresh collected samples of honey were stored in the glass containers and kept in a cool and dark space at temperatures ranging between 4 and $5{ }^{\circ} \mathrm{C}$ until the analyses were performed.

From the homogenized honey samples, $1 \mathrm{~g}$ of each type of honey was digested with $4.0 \mathrm{~mL}$ of $65 \% \mathrm{HNO}_{3}$ and $0.5 \mathrm{~mL}$ of $35 \% \mathrm{H}_{2} \mathrm{O}_{2}$ in PTFE vessels placed in a microwave system.

Soil samples were taken from 5 to $10 \mathrm{~cm}$ after removing the layer from the surface. The samples were sun-dried, homogenized and then the soil samples and propolis samples were dried at $80{ }^{\circ} \mathrm{C}$ until a constant weight was achieved.

The soil and propolis samples were digested at room temperature with $37 \% \mathrm{HCl} / 70 \%$ $\mathrm{HNO}_{3}$ (3:1) mixture (10.0 mL per $0.5 \mathrm{~g}$ of sample) for $12 \mathrm{~h}$. The suspension was then filtered and diluted to $100 \mathrm{~mL}$ with $0.50 \mathrm{M} \mathrm{HNO}_{3}$ for analysis. A blank digestion solution was made for comparison.

$\mathrm{Pb}$ and $\mathrm{Cd}$ levels in the samples were determined using an HGA graphite furnace (PerkinElmer Inc., Waltham, MA, USA), using argon as the inert gas. Other measurements were carried out with an air/acetylene flame (acetylene with a purity of $99.999 \%$ and a flow rate of 1.8-2.0 L/min). All metal reagents were of analytical grade (Merck, Darmstadt, Germany) and double deionized water was used for all dilutions. The resultant solutions were analyzed with an atomic absorption spectrophotometer, Shimadzu AA 6500 (Kyoto, Japan), in order to determine the heavy metal concentrations for cadmium $(\lambda=228.8 \mathrm{~nm})$, cooper $(\lambda=324.7 \mathrm{~nm})$, zinc $(\lambda=213.9 \mathrm{~nm})$, chromium $(\lambda=359.3 \mathrm{~nm})$, lead $(\lambda=283.3 \mathrm{~nm})$, nickel $(\lambda=232 \mathrm{~nm})$ and manganese $(\lambda=279.5 \mathrm{~nm})$. A standard solution for each element under investigation was prepared for calibration.

The linear correlation coefficients $\left(\mathrm{R}^{2}\right)$, limits of detection (LODs) and limits of quantification (LOQs) for each heavy metal analyzed are presented in Table 1.

Table 1. Linear correlation coefficients $\left(\mathrm{R}^{2}\right)$, limits of detection (LOD) and limits of quantification (LOQ) for heavy metals.

\begin{tabular}{cccc}
\hline Element & $\mathbf{R}^{\mathbf{2}}$ & LOD $(\mathbf{m g} / \mathbf{k g})$ & LOQ $\mathbf{( m g / k g )}$ \\
\hline Cadmium & 0.992 & $1.8 \times 10^{-3}$ & $19 \times 10^{-3}$ \\
Copper & 0.998 & $50 \times 10^{-3}$ & $153 \times 10^{-3}$ \\
Zinc & 0.988 & $61 \times 10^{-3}$ & $238 \times 10^{-3}$ \\
Chromium & 0.995 & $52 \times 10^{-3}$ & $165 \times 10^{-3}$ \\
Lead & 1.000 & $49 \times 10^{-3}$ & $166 \times 10^{-3}$ \\
Nickel & 0.999 & $54 \times 10^{-3}$ & $184 \times 10^{-3}$ \\
Manganese & 0.984 & $58 \times 10^{-3}$ & $202 \times 10^{-3}$ \\
\hline
\end{tabular}

\subsubsection{Pesticides Analysis}

Organo-chlorinated pesticides from samples, such as 1,1'-(2,2,2-trichloroethylidene)bis[4-chloro-benzene] ( $p, p^{\prime}$-DDT), 1-chloro-2-[2,2,2-trichloro-1-(4-chlorophenyl)ethyl]-benzene $\left(o, p^{\prime}\right.$-DDT) and 1,1'-(2,2-dichloroethenylidene)-bis[4-chloro-benzene] ( $p, p^{\prime}$-DDE), were detected with the help of a gas chromatograph equipped with an electron detector (ECD).

For pesticides analysis, a $500 \mathrm{~mL}$ aliquot of honey samples was deposited through the separating funnel, to which was added $25 \mathrm{~mL}$ of hexane. The extract was concentrated to about $20 \mathrm{~mL}$ with a Laborota 4001 rotaevaporator and then was treated with Cu to remove the sulfur-containing compounds with a Sonorex RK 52 ultrasonication bath. After that, the samples were transferred onto Florisil columns with a layer of anhydrous sodium sulfate for 
pesticides detection. Pesticides were eluted from the column with dichloromethane/hexane in the $20 \mathrm{~mL}$ fraction, then were concentrated in a KUDERNA-DANISH apparatus to about $1 \mathrm{~mL}$ before being injected into the gas chromatographer.

Dried propolis and soil samples (dried via the aerated method) weighed about $25 \mathrm{~g}$. They were put into a round bottom flask and $100 \mathrm{~mL}$ acetone solvent was added, and then the acetone layer was separated by means of a funnel. The acetone layer was evaporated with an evaporator, extracted with $25 \mathrm{~mL}$ of n-hexane two times, and then cleaned up by passing the sample over the chromatographic column filled with Florisil and anhydrous sodium sulfate. Eluate was evaporated until it reached $1 \mathrm{~mL}$, then was injected into the gas chromatographer.

The pesticide analysis was conducted with a Fisons gas chromatograph equipped with an electron capture detection (ECD) device and a capillary chromatographic column filled with a mixture of silicone oils (QF-1, OV-11, XE-60) on a Chromosorb WHP. Conditions: a $1 \mu \mathrm{L}$ aliquot of the extract was injected; column temperature $200^{\circ} \mathrm{C}$; injector temperature $210{ }^{\circ} \mathrm{C}$; detector temperature $250{ }^{\circ} \mathrm{C}$; carrier gas: nitrogen at a flow rate of $4 \mathrm{~mL} / \mathrm{min}$.

All used reagents were of analytical reagent grade (Merck). Three determinations were made for each investigation.

The linear correlation coefficients $\left(\mathrm{R}^{2}\right)$, limits of detection (LODs) and limits of quantification (LOQs) for each pesticide analyzed are presented in Table 2.

Table 2. Linear correlation coefficients $\left(\mathrm{R}^{2}\right)$, limits of detection (LOD) and limits of quantification (LOQ) for pesticides.

\begin{tabular}{cccc}
\hline Element & $\mathbf{R}^{\mathbf{2}}$ & LOD $(\mathbf{m g} / \mathbf{k g})$ & LOQ $(\mathbf{m g} / \mathbf{k g})$ \\
\hline$p, p^{\prime}$-DDT & 0.994 & $1.95 \times 10^{-3}$ & $12.38 \times 10^{-3}$ \\
$o, p^{\prime}$-DDT & 1.000 & $2.21 \times 10^{-3}$ & $14.35 \times 10^{-3}$ \\
$p, p^{\prime}$-DDE & 0.998 & $2.48 \times 10^{-3}$ & $17.44 \times 10^{-3}$ \\
\hline
\end{tabular}

\subsection{Risk Characterisation for Consumer's Health}

\subsubsection{Bioconcentration Factor}

The bioconcentration factor (BCF) was calculated using the following equation [48]:

$$
\mathrm{BCF}=\mathrm{C} / \mathrm{Cw}
$$

where $C$ is the contaminant concentration in the sample (honey or propolis, $\mu \mathrm{g} / \mathrm{kg}$ ) and $\mathrm{Cw}$ is the contaminant concentration in the soil $(\mu \mathrm{g} / \mathrm{kg})$.

\subsubsection{Estimated Daily Intake (EDI)}

This parameter was obtained using the following equation [49]:

$$
\mathrm{EDI}=\mathrm{C} \times \mathrm{Con} / \mathrm{Bw}
$$

where $\mathrm{C}$ is the average concentration of contaminant concentration in the honey samples $(\mu \mathrm{g} / \mathrm{kg})$, Con is the daily average consumption of honey in Romania ( $\mathrm{kg}_{\text {person }}^{-1} /$ day) and $\mathrm{Bw}$ represents the average body weight.

\subsubsection{Hazard Quotient (HQ)}

This parameter was calculated for each contaminant using the following equation:

$$
\mathrm{HQ}=\mathrm{EDI} / \mathrm{RfD}
$$

where EDI is the estimated daily intake $\left(\mathrm{mg} \mathrm{kg}^{-1}\right.$ day $\left.^{-1}\right)$ and RfD is an approximation of the daily tolerable exposure at which a person is expected to have any significant risk of harmful effects during a lifespan $\left(\mathrm{mg} \mathrm{kg}^{-1} \mathrm{day}^{-1}\right)[50,51]$. 
If the HQ value is less than 1, the exposed population is unlikely to experience any adverse health hazards. To the contrary, if the HQ is equal to or higher than 1 , there is a potential health risk for consumers and protective measurements should be taken.

\subsection{Statistical Analysis}

Statistical analysis was performed using the open-source software $\mathrm{R}$ ( $\mathrm{R}$ version 3.5.3). The basic descriptive statistics, such as mean, standard deviation and standard error, are reported numerically in the tables. A two-way ANOVA using robust estimators was carried out on every element from the groups of metals and pesticides [52]. It is important to specify that our data do not deviate too widely from parametric assumptions. We also use post hoc tests for multiple comparisons based on the bootstrap approach [53]. The statistical significance level was considered at alpha 5\% $(p<0.05)$.

\section{Results}

\subsection{The Concentration of Heavy Metals in Investigated Samples}

The soil samples investigated for the content of heavy metals were within normal limits according to Romanian legislation [54], except for the presence of lead in the soil samples collected from the A1 area, which had concentrations between 51.81 and $52.17 \mathrm{mg} / \mathrm{kg}$. The level of heavy metals in the soil samples collected from the A1 area decrease as follows: $\mathrm{Mn}>\mathrm{Zn}>\mathrm{Pb}>\mathrm{Cr}>\mathrm{Ni}>\mathrm{Cu}>\mathrm{Cd}$. For the $\mathrm{A} 2$ area, the order is: $\mathrm{Mn}>\mathrm{Zn}>\mathrm{Cr}>\mathrm{Cu}>\mathrm{Pb}$ $>\mathrm{Ni}>\mathrm{Cd}$ (Tables 3 and 4 ). This different pattern is due to the significant contamination of the industrial site with lead and the higher amounts of copper that resulted from the fertilizers used in the A2 area.

The propolis samples had the highest content of heavy metals in the A1 area, with the levels as follows: $0.080 \pm 0.006 \mathrm{mg} / \mathrm{kg} \mathrm{Cd}, 3.203 \pm 0.052 \mathrm{mg} / \mathrm{kg} \mathrm{Cu}, 4.195 \pm 0.067 \mathrm{mg} / \mathrm{kg}$ $\mathrm{Zn}, 2.344 \pm 0.074 \mathrm{mg} / \mathrm{kg} \mathrm{Cr}, 0.651 \pm 0.063 \mathrm{mg} / \mathrm{kg} \mathrm{Pb}, 1.146 \pm 0.061 \mathrm{mg} / \mathrm{kg} \mathrm{Zn}$ and $2.184 \pm 0.067 \mathrm{mg} / \mathrm{kg} \mathrm{Mn}$. Lower concentrations were found in propolis from the A2, area with mostly agricultural activity (Table 4 and Figure 1). In the industrial region, the concentration of cadmium in propolis was significantly higher in comparison with the concentration found in honey (two times higher, with a maximum content of $0.088 \mathrm{mg} \mathrm{Cd} / \mathrm{kg}$ in propolis).

Mean metal concentrations with their standard deviations are shown in Tables 3 and 4. The average concentrations of the seven heavy metals in the honey samples collected in the region with intense industrial activity decrease as follows: $\mathrm{Zn}>\mathrm{Cu}>\mathrm{Cr}>\mathrm{Mn}>\mathrm{Ni}>\mathrm{Pb}>\mathrm{Cd}$. In the region characterized by agricultural activity, the order is: $\mathrm{Cr}>\mathrm{Zn}>\mathrm{Mn}>\mathrm{Ni}>\mathrm{Cu}>$ $\mathrm{Pb}>\mathrm{Cd}$.

The amount of heavy metals in the honey samples from the A1 area was higher than those from the $\mathrm{A} 2$ area. The concentrations of $\mathrm{Cd}, \mathrm{Cu}, \mathrm{Zn}, \mathrm{Cr}, \mathrm{Pb}, \mathrm{Ni}$ and $\mathrm{Mn}$ in the industrial region vary between 0.02 and $0.074 \mathrm{mg} / \mathrm{kg}, 1.03$ and $2.54 \mathrm{mg} / \mathrm{kg}, 3.09$ and $3.99 \mathrm{mg} / \mathrm{kg}, 1.04$ and $1.94 \mathrm{mg} / \mathrm{kg}, 0.11$ and $0.63 \mathrm{mg} / \mathrm{kg}, 0.39$ and $0.96 \mathrm{mg} / \mathrm{kg}$ and 1.18 and $1.95 \mathrm{mg} / \mathrm{kg}$, respectively. The content of $\mathrm{Cd}, \mathrm{Cu}, \mathrm{Zn}, \mathrm{Cr}, \mathrm{Pb}, \mathrm{Ni}$ and $\mathrm{Mn}$ in the A2 are situated between 0.003 and $0.021 \mathrm{mg} / \mathrm{kg}, 0.12$ and $0.48 \mathrm{mg} / \mathrm{kg}, 0.66$ and $0.99 \mathrm{mg} / \mathrm{kg}$, 0.61 and $0.68 \mathrm{mg} / \mathrm{kg}, 0.04$ and $0.21 \mathrm{mg} / \mathrm{kg}, 0.39$ and $0.79 \mathrm{mg} / \mathrm{kg}$ and 1.22 and $1.79 \mathrm{mg} / \mathrm{kg}$, respectively. The mean concentrations of heavy metals in the honey samples collected from the study areas are presented in Tables 3 and 4 and Figure 1.

The content of heavy metals in the analyzed honey samples exceeded the maximum allowable levels established by the Commission Regulation (EC) no. 1881/2006 in the case of cadmium, copper, lead and zinc [55], and also in the Codex Alimentarius [56] and Council Directive 2001/110/EC relating to honey [57], in the case of the samples collected from the A1 area (with intense industrial activity) (Table 3). No thresholds for nickel, chromium or manganese have yet been set for this food category.

All samples of honey and propolis analyzed from A2 area showed values for the concentrations of heavy metals below the maximum allowable level (Table 4). 
Especially in the case of cadmium, the mean concentration in the honey samples collected from the A1 area $(0.042 \mathrm{mg} / \mathrm{kg})$ was much higher than that found in the A2 area $(0.013 \mathrm{mg} / \mathrm{kg})(p<0.0001)$. All types of honey had a higher amount of $\mathrm{Cd}$ in the industrial region than those collected from the A2 area (with agricultural activity), with a maximum in rapeseed honey (see Tables 3 and 4). A two-way ANOVA was carried out on cadmium levels according to location type and sample and both main effects were statistically significant. There was a statistically significant interaction between the effects of location and sample types on cadmium levels $(\mathrm{F}=3.669, p<0.0001)$. Post hoc tests were carried out for all pairwise comparisons for the means of Cadmium levels considering the full set of interactions. There was a statistically significant relationship between all groups of the same type of honey $(p<0.0001)$, but it was noticed that the same level of cadmium was present in honey types from A2 area(the area with the lowest level of cadmium in the soil).

The same statistical analyses were applied in the case of copper and the results show a statistically significant interaction between the location and type of sample $(\mathrm{F}=3.6$; $p<0.001)$. Post hoc tests revealed statistically significant differences between the same type of honey collected from A1 and A2 areas $(p<0.0001)$. Similar levels of copper $(p>0.9)$ had been observed in A2 area in the case of linden and black locust honeys and also in the case of multiple comparisons between propolis, multifloral and rapeseed honeys.

Statistically significant differences were observed in the case of lead levels according to location and type of honey sample $(\mathrm{F}=71.68 ; p<0.0001)$. Lead levels in propolis and honey samples from the industrial region were significantly higher than those from the A2 area $(p<0.0001)$ and a similar level of contamination was detected between all A2 area samples $(p>0.1)$. These findings are in accordance with other research conducted in Romania, Turkey and Poland [58-60].

A significantly increased zinc level was detected in all samples of the A1 area in comparison with the A2 area $(p<0.0001)$ and no statistically significance differences in zinc levels were determined between the honey samples and propolis in the industrial area $(p>0.1)$.

Table 3. Heavy metal concentrations (mean \pm standard deviation) $(\mathrm{mg} / \mathrm{kg})$ in honey, propolis and soil samples collected from area A1 (area with intense industrial activity).

\begin{tabular}{|c|c|c|c|c|c|c|c|}
\hline Sample & $\mathrm{Cd}$ & $\mathrm{Cu}$ & Zn & $\mathrm{Cr}$ & $\mathrm{Pb}$ & $\mathrm{Ni}$ & Mn \\
\hline Black locust honey & $0.047 \pm 0.009$ & $2.132 \pm 0.066$ & $3.502 \pm 0.052$ & $1.729 \pm 0.059$ & $0.213 \pm 0.073$ & $0.828 \pm 0.058$ & $1.518 \pm 0.075$ \\
\hline Linden honey & $0.028 \pm 0.006$ & $1.599 \pm 0.052$ & $3.793 \pm 0.056$ & $1.507 \pm 0.083$ & $0.294 \pm 0.055$ & $0.698 \pm 0.062$ & $1.107 \pm 0.047$ \\
\hline Multifloral honey & $0.030 \pm 0.006$ & $1.134 \pm 0.065$ & $3.886 \pm 0.062$ & $1.869 \pm 0.068$ & $0.539 \pm 0.054$ & $0.485 \pm 0.070$ & $1.838 \pm 0.069$ \\
\hline Rapeseed honey & $0.063 \pm 0.007$ & $2.422 \pm 0.064$ & $3.188 \pm 0.068$ & $1.272 \pm 0.051$ & $0.274 \pm 0.058$ & $0.858 \pm 0.074$ & $1.662 \pm 0.075$ \\
\hline Propolis & $0.080 \pm 0.006$ & $3.203 \pm 0.052$ & $4.195 \pm 0.067$ & $2.344 \pm 0.074$ & $0.651 \pm 0.063$ & $1.146 \pm 0.061$ & $2.184 \pm 0.067$ \\
\hline Soil & $3.599 \pm 0.061$ & $25.056 \pm 0.092$ & $135.012 \pm 0.089$ & $34.078 \pm 0.090$ & $51.979 \pm 0.121$ & $26.931 \pm 0.096$ & $425.983 \pm 0.121$ \\
\hline $\begin{array}{l}\text { MAL * } \mathbf{~ m g / k g ~ i n ~} \\
\text { honey [55-57] }\end{array}$ & 0.02 & 0.50 & 1.00 & - & 0.2 & - & \\
\hline$\underset{\text { soil [54] }}{\text { MAL }}$ mg/kg dry & 3 & 100 & 300 & 100 & 50 & 50 & 1500 \\
\hline
\end{tabular}

* MAL-maximum allowable level.

Table 4. Heavy metal concentrations (mean \pm standard deviation) ( $\mathrm{mg} / \mathrm{kg}$ ) in honey, propolis and soil samples collected from A2 area (entirely devoid of industrial activity, but with moderate agricultural activity).

\begin{tabular}{|c|c|c|c|c|c|c|c|}
\hline Sample & $\mathrm{Cd}$ & $\mathrm{Cu}$ & Zn & $\mathrm{Cr}$ & $\mathrm{Pb}$ & $\mathrm{Ni}$ & Mn \\
\hline Black locust honey & $0.014 \pm 0.004$ & $0.216 \pm 0.062$ & $0.807 \pm 0.052$ & $1.408 \pm 0.067$ & $0.141 \pm 0.048$ & $0.623 \pm 0.064$ & $0.724 \pm 0.080$ \\
\hline Linden honey & $0.016 \pm 0.003$ & $0.290 \pm 0.055$ & $0.885 \pm 0.060$ & $1.498 \pm 0.065$ & $0.138 \pm 0.047$ & $0.488 \pm 0.067$ & $0.877 \pm 0.062$ \\
\hline Multifloral honey & $0.013 \pm 0.005$ & $0.384 \pm 0.057$ & $0.882 \pm 0.062$ & $1.332 \pm 0.067$ & $0.120 \pm 0.048$ & $0.663 \pm 0.093$ & $0.841 \pm 0.068$ \\
\hline Rapeseed honey & $0.012 \pm 0.004$ & $0.399 \pm 0.055$ & $0.774 \pm 0.072$ & $1.702 \pm 0.067$ & $0.134 \pm 0.042$ & $0.564 \pm 0.079$ & $0.738 \pm 0.085$ \\
\hline Propolis & $0.016 \pm 0.004$ & $0.402 \pm 0.059$ & $0.947 \pm 0.090$ & $1.868 \pm 0.065$ & $0.160 \pm 0.044$ & $0.876 \pm 0.082$ & $1.026 \pm 0.086$ \\
\hline Soil & $1.649 \pm 0.091$ & $20.049 \pm 0.093$ & $98.01 \pm 0.095$ & $27.148 \pm 0.063$ & $19.579 \pm 0.069$ & $18.881 \pm 0.070$ & $412.976 \pm 0.124$ \\
\hline $\begin{array}{l}\text { MAL * } \mathbf{~ m g / k g ~ i n ~} \\
\text { honey [55-57] }\end{array}$ & 0.02 & 0.50 & 1.00 & - & 0.2 & - & \\
\hline$\underset{\text { soil [54] }}{\text { MAL }}$ mg/kg dry & 3 & 100 & 300 & 100 & 50 & 50 & 1500 \\
\hline
\end{tabular}



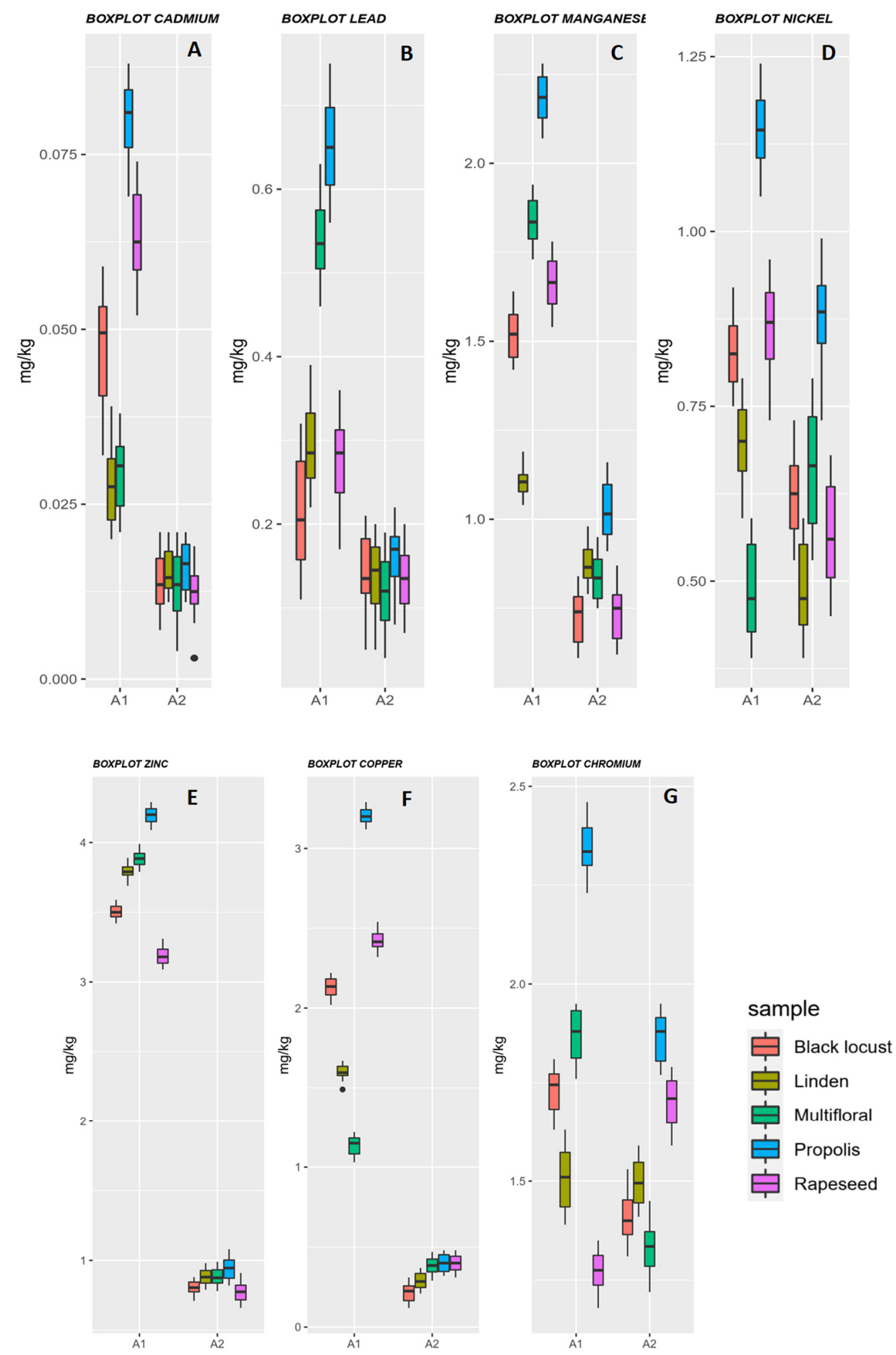

Figure 1. Heavy metal level variations $(\mathrm{mg} / \mathrm{kg}$ ) in honey samples in A1 (industrial activity) and A2 (agricultural activity) areas: (A) nickel, (B) chromium, (C) zinc, (D) copper, (E) cadmium, (F) lead and $(\mathbf{G})$ manganese.

\subsection{The Concentration of Pesticides in Investigated Samples}

Pesticide concentrations ( $p, p^{\prime}$-DDT, $o, p^{\prime}$-DDT and $p, p^{\prime}$-DDE) in the honey, propolis and soil samples collected from the studied areas are presented in Table 5 and Figures 2 and 3. 
Table 5. Pesticide concentrations (mean \pm standard deviation) $(\mathrm{mg} / \mathrm{kg}$ ) in honey, propolis and soil samples collected from studied areas (A1 area with intense industrial activity, A2 area with entirely devoid of industrial activity, but with moderate agricultural activity).

\begin{tabular}{|c|c|c|c|}
\hline Sample & $p, p^{\prime}-\mathrm{DDT}$ & $o, p^{\prime}-\mathrm{DDT}$ & $p, p^{\prime}-\mathrm{DDE}$ \\
\hline \multicolumn{4}{|c|}{ A1 Area } \\
\hline Black locust honey & $0.0261 \pm 0.0044$ & $0.0200 \pm 0.0063$ & $0.0201 \pm 0.0042$ \\
\hline Linden honey & $0.0179 \pm 0.0045$ & $0.0163 \pm 0.0094$ & $0.0150 \pm 0.0026$ \\
\hline Multifloral honey & $0.0311 \pm 0.0042$ & $0.0166 \pm 0.0057$ & $0.0297 \pm 0.0067$ \\
\hline Rapeseed honey & $0.0266 \pm 0.0045$ & $0.0217 \pm 0.0061$ & $0.0210 \pm 0.0044$ \\
\hline Propolis & $0.0320 \pm 0.0062$ & $0.0247 \pm 0.0044$ & $0.0300 \pm 0.0052$ \\
\hline Soil & $0.0485 \pm 0.0080$ & $0.0422 \pm 0.0063$ & $0.0535 \pm 0.0075$ \\
\hline \multicolumn{4}{|c|}{ A2 Area } \\
\hline Black locust honey & $0.0066 \pm 0.0036$ & $0.0118 \pm 0.0035$ & $0.0101 \pm 0.0048$ \\
\hline Linden honey & $0.0055 \pm 0.0037$ & $0.0067 \pm 0.0047$ & $0.0058 \pm 0.0037$ \\
\hline Multifloral honey & $0.0138 \pm 0.0046$ & $0.0068 \pm 0.0041$ & $0.0123 \pm 0.0051$ \\
\hline Rapeseed honey & $0.0137 \pm 0.0048$ & $0.0105 \pm 0.0052$ & $0.0095 \pm 0.0052$ \\
\hline Propolis & $0.0127 \pm 0.0052$ & $0.0115 \pm 0.0044$ & $0.0149 \pm 0.0044$ \\
\hline Soil & $0.0132 \pm 0.0043$ & $0.0156 \pm 0.0054$ & $0.0177 \pm 0.0063$ \\
\hline MAL * mg/kg honey [61] & & Total DDT 0.05 & \\
\hline MAL * mg/kg dry soil [54] & 0.25 & 0.25 & 0.25 \\
\hline
\end{tabular}

BOXPLOT PPDDT

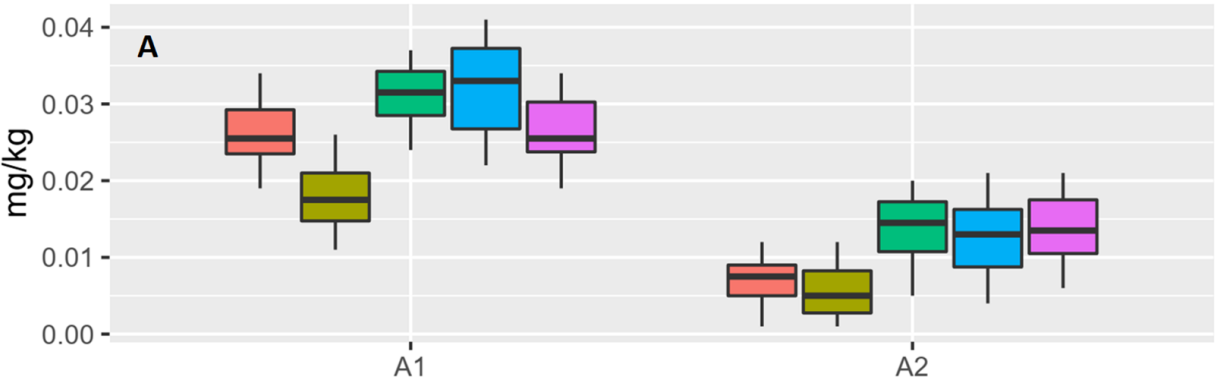

sample

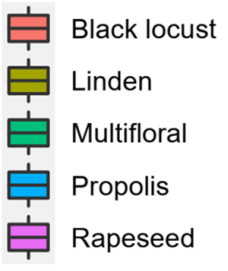

BOXPLOT OPDDT

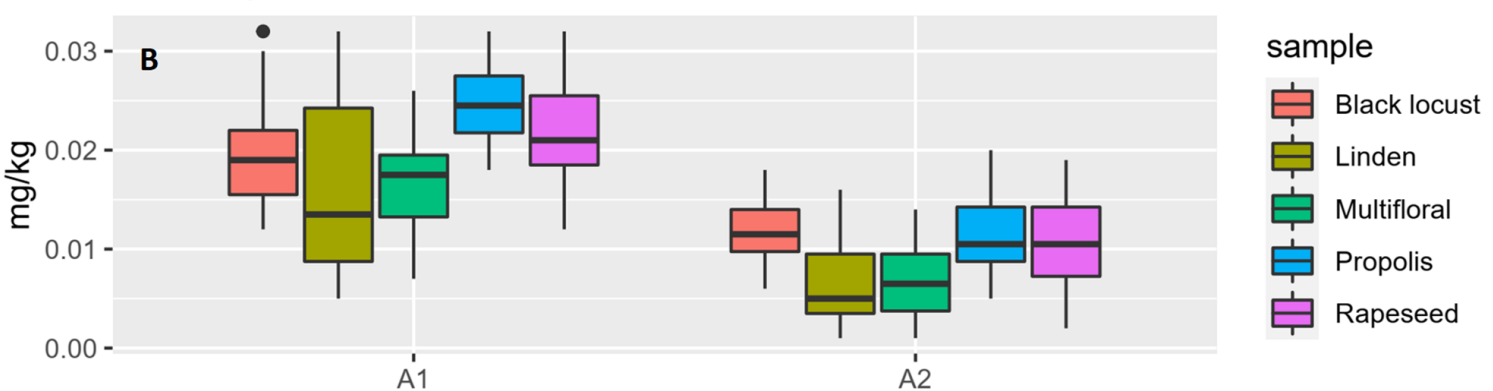

BOXPLOT PPDDE

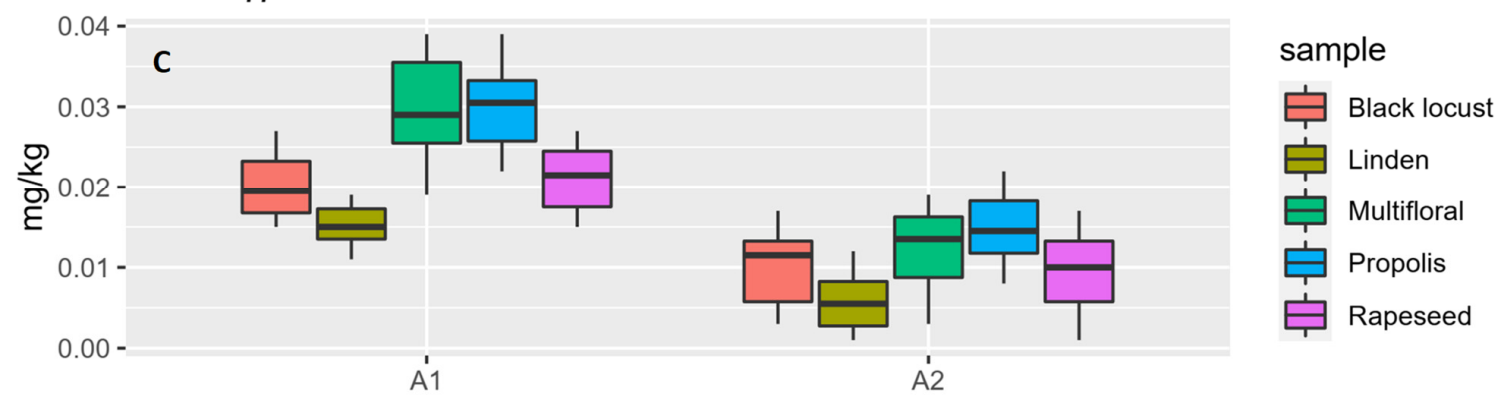

Figure 2. Pesticide level variations in honey samples $(\mathrm{mg} / \mathrm{kg})$ in A1 area(industrial activity) and A2 area(agricultural activity): (A) $p, p^{\prime}$-DDT, (B) $o, p^{\prime}$-DDT and (C) $p, p^{\prime}$-DDE. 
BOXPLOT PDDDT

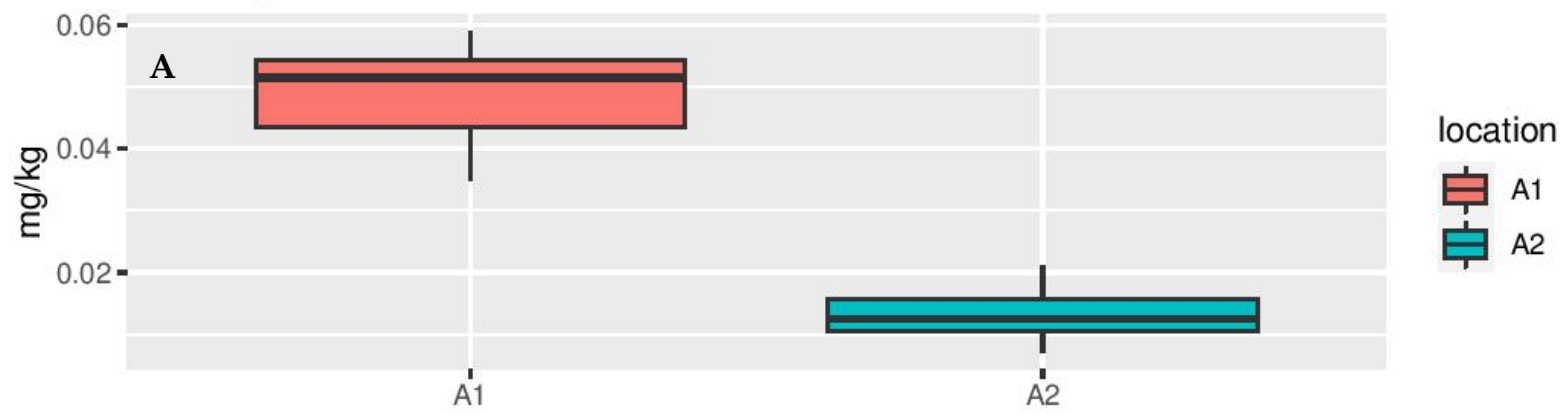

BOXPLOT OPDDT

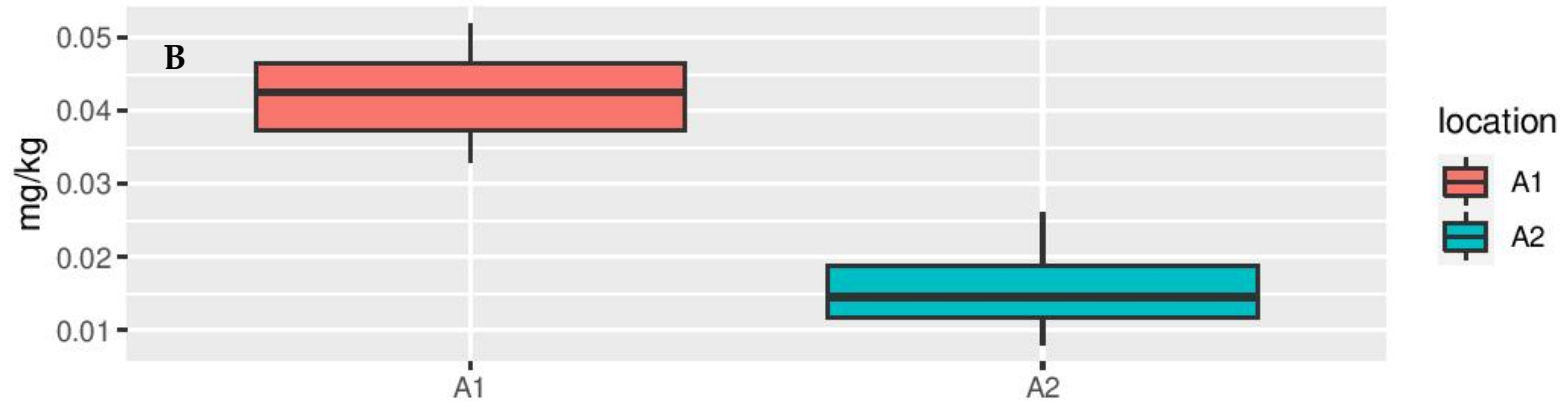

BOXPLOT PDDDE

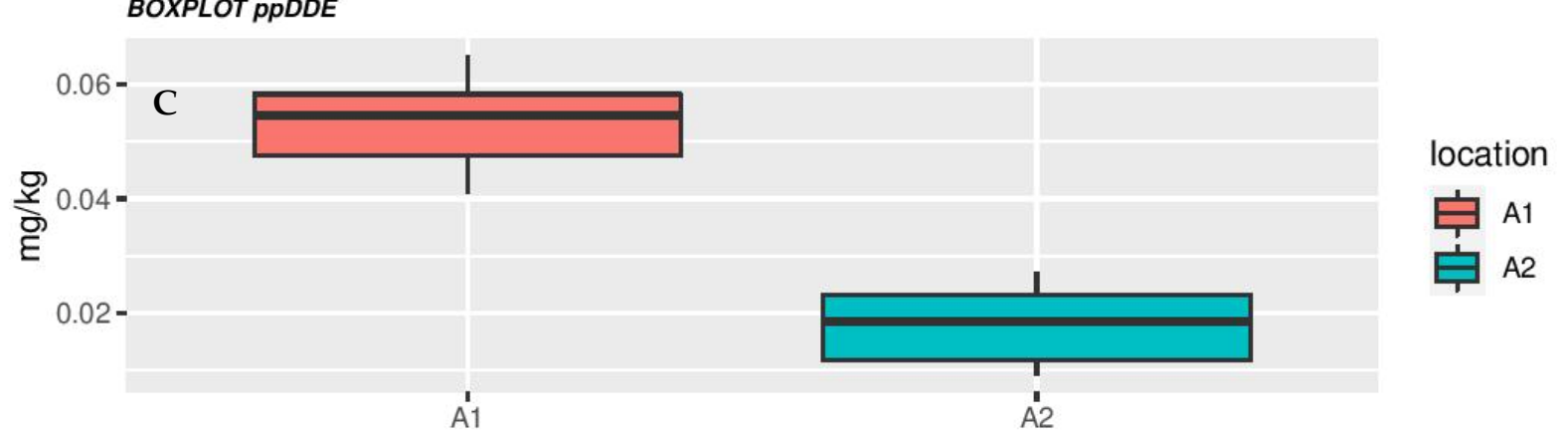

Figure 3. Pesticide level variations in soil samples from A1 area (industrial activity) and A2 area (agricultural activity): (A) $p, p^{\prime}$-DDT, (B) $o, p^{\prime}$-DDT and (C) $p, p^{\prime}$-DDE.

The content of DDT metabolites had the highest concentrations in the honey samples from the industrial site, being significantly higher than the agricultural site by 2.3 times $(p<0.001)$. The highest pesticide content was found in the multifloral type and the lowest in the linden honey. At the same time, the sum of the three DDT metabolites exceeds the maximum allowable level for foodstuffs, suggesting that there is a great persistence of these chemicals in environmental components, although they have been forbidden and not been used for decades. Nevertheless, the pesticide content of the soil samples was within normal limits both in the A1 and A2 areas.

As in the case of the honey samples, propolis had the highest content of pesticides in the industrial area, with the total DDT concentration $(0.0867 \mathrm{mg} / \mathrm{kg})$ exceeding by 1.7 times the maximum allowable level for foodstuffs [61].

The experimental data also indicate pesticide values below the maximum allowable level in the samples of honey and propolis harvested from the area with agricultural activity (Table 5). 


\subsection{Heavy Metal and Pesticide Accumulation from Soil to Bees' Products}

The chemical transfer from soil to plants and then to bees' bodies and their products has been investigated in several studies [62-64]. In our study, the analysis of the bioconcentration factors revealed that the black locust honey, rapeseed honey and propolis bioaccumulates $\mathrm{Cd}$ and $\mathrm{Cu}$ in high amounts in the industrial region (Tables 6 and 7). Mn and $\mathrm{Pb}$ were less transferred from soil to honey and propolis. In the $\mathrm{A} 1$ area, $\mathrm{Mn}$ was transferred especially to black locust and multifloral honey, as well as propolis. In contrast to samples collected from the A1 area, a high bioaccumulation of Mn was registered in linden and rapeseed honey from the region with moderate agricultural activity, but without industrial activity. High bioaccumulation of $\mathrm{Cr}$ was observed in black locust honey (A2 area) and multifloral honey (A1 area).

The results indicate that propolis accumulates all investigated heavy metals to a high extent in both studied areas (Tables 6-15).

The experimental results indicate a higher bioaccumulation of pesticides in the samples of honey and propolis collected from the area with industrial activity (Tables 13-15).

Table 6. Bioconcentration factor for Cd.

\begin{tabular}{ccccccc}
\hline Sample & Area & Mean Value & $\begin{array}{c}\text { Standard } \\
\text { Deviation }\end{array}$ & $\begin{array}{c}\text { Standard } \\
\text { Error }\end{array}$ & $\begin{array}{c}\text { Minimal } \\
\text { Value }\end{array}$ & $\begin{array}{c}\text { Maximal } \\
\text { Value }\end{array}$ \\
\hline Black locust honey & A1 & 0.013 & 0.002 & 0.001 & 0.009 & 0.016 \\
Linden honey & A2 & 0.008 & 0.003 & 0.001 & 0.004 & 0.013 \\
& A1 & 0.008 & 0.002 & 0.0002 & 0.006 & 0.011 \\
Multifloral honey & A2 & 0.009 & 0.002 & 0.001 & 0.007 & 0.013 \\
\multirow{2}{*}{ Rapeseed honey } & A1 & 0.008 & 0.002 & 0.0002 & 0.006 & 0.011 \\
& A2 & 0.008 & 0.003 & 0.001 & 0.002 & 0.013 \\
Propolis & A2 & 0.018 & 0.002 & 0.001 & 0.014 & 0.021 \\
& A1 & 0.008 & 0.003 & 0.001 & 0.002 & 0.019 \\
\hline
\end{tabular}

Table 7. Bioconcentration factor for $\mathrm{Cu}$.

\begin{tabular}{|c|c|c|c|c|c|c|}
\hline Sample & Area & Mean Value & $\begin{array}{l}\text { Standard } \\
\text { Deviation }\end{array}$ & $\begin{array}{c}\text { Standard } \\
\text { Error }\end{array}$ & $\underset{\text { Value }}{\text { Minimal }}$ & $\underset{\text { Value }}{\text { Maximal }}$ \\
\hline \multirow[t]{2}{*}{ Black locust honey } & A1 & 0.085 & 0.003 & 0.001 & 0.081 & 0.089 \\
\hline & A2 & 0.011 & 0.003 & 0.001 & 0.006 & 0.015 \\
\hline \multirow[t]{2}{*}{ Linden honey } & A1 & 0.064 & 0.002 & 0.001 & 0.059 & 0.067 \\
\hline & A2 & 0.014 & 0.003 & 0.001 & 0.01 & 0.018 \\
\hline \multirow[t]{2}{*}{ Multifloral honey } & A1 & 0.045 & 0.003 & 0.001 & 0.041 & 0.049 \\
\hline & A2 & 0.019 & 0.003 & 0.001 & 0.014 & 0.023 \\
\hline \multirow[t]{2}{*}{ Rapeseed honey } & $\mathrm{A} 1$ & 0.097 & 0.003 & 0.001 & 0.093 & 0.101 \\
\hline & A2 & 0.020 & 0.003 & 0.001 & 0.015 & 0.024 \\
\hline \multirow{2}{*}{ Propolis } & $\mathrm{A} 1$ & 0.128 & 0.002 & 0.001 & 0.125 & 0.131 \\
\hline & A2 & 0.020 & 0.003 & 0.001 & 0.016 & 0.024 \\
\hline
\end{tabular}

Table 8. Bioconcentration factor for $\mathrm{Zn}$.

\begin{tabular}{|c|c|c|c|c|c|c|}
\hline Sample & Area & Mean Value & $\begin{array}{c}\text { Standard } \\
\text { Deviation }\end{array}$ & $\begin{array}{l}\text { Standard } \\
\text { Error }\end{array}$ & $\begin{array}{c}\text { Minimal } \\
\text { Value }\end{array}$ & $\underset{\text { Value }}{\text { Maximal }}$ \\
\hline \multirow[t]{2}{*}{ Black locust honey } & A1 & 0.026 & 0.0002 & 0.001 & 0.025 & 0.027 \\
\hline & A2 & 0.008 & 0.001 & 0.002 & 0.007 & 0.009 \\
\hline \multirow[t]{2}{*}{ Linden honey } & A1 & 0.028 & 0.0002 & 0.001 & 0.027 & 0.029 \\
\hline & A2 & 0.009 & 0.001 & 0.002 & 0.008 & 0.010 \\
\hline \multirow[t]{2}{*}{ Multifloral honey } & $\mathrm{A} 1$ & 0.029 & 0.0002 & 0.001 & 0.028 & 0.030 \\
\hline & A2 & 0.009 & 0.001 & 0.002 & 0.008 & 0.010 \\
\hline \multirow{2}{*}{ Rapeseed honey } & A1 & 0.024 & 0.001 & 0.002 & 0.023 & 0.025 \\
\hline & A2 & 0.008 & 0.001 & 0.003 & 0.007 & 0.009 \\
\hline \multirow{2}{*}{ Propolis } & $\mathrm{A} 1$ & 0.031 & 0.0002 & 0.001 & 0.030 & 0.032 \\
\hline & A2 & 0.010 & 0.001 & 0.003 & 0.008 & 0.011 \\
\hline
\end{tabular}


Table 9. Bioconcentration factor for $\mathrm{Cr}$.

\begin{tabular}{|c|c|c|c|c|c|c|}
\hline Sample & Area & Mean Value & $\begin{array}{l}\text { Standard } \\
\text { Deviation }\end{array}$ & $\begin{array}{l}\text { Standard } \\
\text { Error }\end{array}$ & $\begin{array}{l}\text { Minimal } \\
\text { Value }\end{array}$ & $\begin{array}{c}\text { Maximal } \\
\text { Value }\end{array}$ \\
\hline \multirow[t]{2}{*}{ Black locust honey } & A1 & 0.051 & 0.002 & 0.001 & 0.048 & 0.053 \\
\hline & $\mathrm{A} 2$ & 0.052 & 0.002 & 0.001 & 0.048 & 0.056 \\
\hline \multirow[t]{2}{*}{ Linden honey } & A1 & 0.044 & 0.002 & 0.001 & 0.041 & 0.048 \\
\hline & $\mathrm{A} 2$ & 0.055 & 0.002 & 0.001 & 0.052 & 0.059 \\
\hline \multirow[t]{2}{*}{ Multifloral honey } & A1 & 0.055 & 0.002 & 0.001 & 0.052 & 0.057 \\
\hline & $\mathrm{A} 2$ & 0.049 & 0.002 & 0.001 & 0.045 & 0.053 \\
\hline \multirow[t]{2}{*}{ Rapeseed honey } & A1 & 0.037 & 0.002 & 0.0006 & 0.035 & 0.040 \\
\hline & $\mathrm{A} 2$ & 0.063 & 0.002 & 0.001 & 0.059 & 0.066 \\
\hline \multirow[t]{2}{*}{ Propolis } & A1 & 0.069 & 0.002 & 0.001 & 0.065 & 0.072 \\
\hline & A2 & 0.069 & 0.002 & 0.001 & 0.065 & 0.072 \\
\hline
\end{tabular}

Table 10. Bioconcentration factor for $\mathrm{Pb}$.

\begin{tabular}{|c|c|c|c|c|c|c|}
\hline Sample & Area & Mean Value & $\begin{array}{l}\text { Standard } \\
\text { Deviation }\end{array}$ & $\begin{array}{c}\text { Standard } \\
\text { Error }\end{array}$ & $\begin{array}{l}\text { Minimal } \\
\text { Value }\end{array}$ & $\begin{array}{c}\text { Maximal } \\
\text { Value }\end{array}$ \\
\hline \multirow[t]{2}{*}{ Black locust honey } & A1 & 0.004 & 0.001 & 0.0002 & 0.002 & 0.006 \\
\hline & $\mathrm{A} 2$ & 0.007 & 0.002 & 0.001 & 0.003 & 0.011 \\
\hline \multirow[t]{2}{*}{ Linden honey } & A1 & 0.006 & 0.001 & 0.0003 & 0.004 & 0.008 \\
\hline & $\mathrm{A} 2$ & 0.007 & 0.002 & 0.001 & 0.003 & 0.010 \\
\hline \multirow[t]{2}{*}{ Multifloral honey } & A1 & 0.010 & 0.001 & 0.0002 & 0.009 & 0.012 \\
\hline & A2 & 0.006 & 0.002 & 0.001 & 0.002 & 0.010 \\
\hline \multirow[t]{2}{*}{ Rapeseed honey } & A1 & 0.005 & 0.001 & 0.0001 & 0.003 & 0.007 \\
\hline & $\mathrm{A} 2$ & 0.007 & 0.002 & 0.001 & 0.004 & 0.010 \\
\hline \multirow[t]{2}{*}{ Propolis } & A1 & 0.013 & 0.001 & 0.0004 & 0.011 & 0.014 \\
\hline & $\mathrm{A} 2$ & 0.008 & 0.002 & 0.001 & 0.004 & 0.011 \\
\hline
\end{tabular}

Table 11. Bioconcentration factor for Ni.

\begin{tabular}{ccccccc}
\hline Sample & Area & Mean Value & $\begin{array}{c}\text { Standard } \\
\text { Deviation }\end{array}$ & $\begin{array}{c}\text { Standard } \\
\text { Error }\end{array}$ & $\begin{array}{c}\text { Minimal } \\
\text { Value }\end{array}$ & $\begin{array}{c}\text { Maximal } \\
\text { Value }\end{array}$ \\
\hline Black locust & A1 & 0.031 & 0.002 & 0.001 & 0.028 & 0.034 \\
honey & A2 & 0.033 & 0.003 & 0.001 & 0.028 & 0.039 \\
Linden honey & A1 & 0.026 & 0.002 & 0.001 & 0.022 & 0.029 \\
& A2 & 0.026 & 0.004 & 0.001 & 0.021 & 0.031 \\
Multifloral honey & A1 & 0.018 & 0.003 & 0.001 & 0.014 & 0.022 \\
Rapeseed honey & A2 & 0.035 & 0.005 & 0.001 & 0.028 & 0.027 \\
A1 & A2 & 0.032 & 0.003 & 0.001 & 0.024 & 0.036 \\
& A1 & 0.030 & 0.004 & 0.001 & 0.039 & 0.046 \\
& A2 & 0.043 & 0.002 & 0.001 & 0.039 & 0.052 \\
\hline
\end{tabular}

Table 12. Bioconcentration factor for Mn.

\begin{tabular}{ccccccc}
\hline Sample & Area & Mean Value & $\begin{array}{c}\text { Standard } \\
\text { Deviation }\end{array}$ & $\begin{array}{c}\text { Standard } \\
\text { Error }\end{array}$ & $\begin{array}{c}\text { Minimal } \\
\text { Value }\end{array}$ & $\begin{array}{c}\text { Maximal } \\
\text { Value }\end{array}$ \\
\hline Black locust & A1 & 0.00356 & 0.00018 & 0.00005 & 0.00333 & 0.00385 \\
honey & A2 & 0.00175 & 0.00019 & 0.00006 & 0.00148 & 0.00203 \\
Linden honey & A1 & 0.0026 & 0.00011 & 0.00003 & 0.00244 & 0.00279 \\
& A2 & 0.00212 & 0.00015 & 0.00004 & 0.00191 & 0.00237 \\
Multifloral honey & A1 & 0.00432 & 0.00016 & 0.00005 & 0.00406 & 0.00455 \\
Rapeseed honey & A2 & 0.00204 & 0.00017 & 0.00005 & 0.00182 & 0.0023 \\
A1 & A2 & 0.0039 & 0.00018 & 0.00005 & 0.00362 & 0.00418 \\
& A1 & 0.00179 & 0.00021 & 0.00006 & 0.0015 & 0.00211 \\
& A2 & 0.00513 & 0.00016 & 0.00005 & 0.00486 & 0.00535 \\
\hline
\end{tabular}


Table 13. Bioconcentration factor for $p, p^{\prime}$-DDT.

\begin{tabular}{|c|c|c|c|c|c|c|}
\hline Sample & Area & Mean Value & $\begin{array}{l}\text { Standard } \\
\text { Deviation }\end{array}$ & $\begin{array}{l}\text { Standard } \\
\text { Error }\end{array}$ & $\begin{array}{l}\text { Minimal } \\
\text { Value }\end{array}$ & $\begin{array}{l}\text { Maximal } \\
\text { Value }\end{array}$ \\
\hline \multirow[t]{2}{*}{ Black locust honey } & A1 & 0.545 & 0.094 & 0.027 & 0.396 & 0.708 \\
\hline & $\mathrm{A} 2$ & 0.513 & 0.283 & 0.082 & 0.077 & 0.923 \\
\hline \multirow[t]{2}{*}{ Linden honey } & A1 & 0.373 & 0.094 & 0.027 & 0.229 & 0.542 \\
\hline & $\mathrm{A} 2$ & 0.423 & 0.291 & 0.084 & 0.077 & 0.923 \\
\hline \multirow[t]{2}{*}{ Multifloral honey } & A1 & 0.649 & 0.088 & 0.025 & 0.500 & 0.771 \\
\hline & $\mathrm{A} 2$ & 0.064 & 0.355 & 0.102 & 0.385 & 1.538 \\
\hline \multirow[t]{2}{*}{ Rapeseed honey } & A1 & 0.556 & 0.094 & 0.027 & 0.396 & 0.708 \\
\hline & $\mathrm{A} 2$ & 0.058 & 0.373 & 0.108 & 0.462 & 1.615 \\
\hline \multirow[t]{2}{*}{ Propolis } & A1 & 0.668 & 0.129 & 0.037 & 0.458 & 0.854 \\
\hline & A2 & 0.981 & 0.403 & 0.116 & 0.308 & 1.615 \\
\hline
\end{tabular}

Table 14. Bioconcentration factor for $o, p^{\prime}$-DDT.

\begin{tabular}{|c|c|c|c|c|c|c|}
\hline Sample & Area & Mean Value & $\begin{array}{l}\text { Standard } \\
\text { Deviation }\end{array}$ & $\begin{array}{c}\text { Standard } \\
\text { Error }\end{array}$ & $\begin{array}{l}\text { Minimal } \\
\text { Value }\end{array}$ & $\begin{array}{c}\text { Maximal } \\
\text { Value }\end{array}$ \\
\hline \multirow[t]{2}{*}{ Black locust honey } & A1 & 0.476 & 0.151 & 0.044 & 0.286 & 0.762 \\
\hline & A2 & 0.789 & 0.238 & 0.069 & 0.4 & 1.2 \\
\hline \multirow[t]{2}{*}{ Linden honey } & $\mathrm{A} 1$ & 0.389 & 0.224 & 0.065 & 0.119 & 0.762 \\
\hline & A2 & 0.450 & 0.314 & 0.091 & 0.067 & 1.067 \\
\hline \multirow[t]{2}{*}{ Multifloral honey } & A1 & 0.397 & 0.136 & 0.039 & 0.167 & 0.619 \\
\hline & $\mathrm{A} 2$ & 0.456 & 0.274 & 0.079 & 0.067 & 0.933 \\
\hline \multirow[t]{2}{*}{ Rapeseed honey } & A1 & 0.518 & 0.145 & 0.042 & 0.286 & 0.762 \\
\hline & A2 & 0.700 & 0.350 & 0.101 & 0.133 & 1.267 \\
\hline \multirow[t]{2}{*}{ Propolis } & A1 & 0.589 & 0.107 & 0.031 & 0.429 & 0.762 \\
\hline & $\mathrm{A} 2$ & 0.767 & 0.293 & 0.085 & 0.333 & 1.333 \\
\hline
\end{tabular}

Table 15. Bioconcentration factor for $p, p^{\prime}$-DDE.

\begin{tabular}{|c|c|c|c|c|c|c|}
\hline Sample & Area & Mean Value & $\begin{array}{l}\text { Standard } \\
\text { Deviation }\end{array}$ & $\begin{array}{l}\text { Standard } \\
\text { Error }\end{array}$ & $\begin{array}{c}\text { Minimal } \\
\text { Value }\end{array}$ & $\begin{array}{c}\text { Maximal } \\
\text { Value }\end{array}$ \\
\hline \multirow[t]{2}{*}{ Black locust honey } & A1 & 0.381 & 0.080 & 0.080 & 0.283 & 0.509 \\
\hline & A2 & 0.598 & 0.287 & 0.287 & 0.176 & 1 \\
\hline \multirow[t]{2}{*}{ Linden honey } & A1 & 0.285 & 0.049 & 0.049 & 0.208 & 0.358 \\
\hline & $\mathrm{A} 2$ & 0.343 & 0.223 & 0.223 & 0.059 & 0.706 \\
\hline \multirow[t]{2}{*}{ Multifloral honey } & A1 & 0.561 & 0.126 & 0.126 & 0.358 & 0.736 \\
\hline & $\mathrm{A} 2$ & 0.725 & 0.304 & 0.304 & 0.176 & 1.118 \\
\hline \multirow[t]{2}{*}{ Rapeseed honey } & $\mathrm{A} 1$ & 0.398 & 0.085 & 0.085 & 0.415 & 0.736 \\
\hline & $\mathrm{A} 2$ & 0.559 & 0.309 & 0.309 & 0.471 & 1.294 \\
\hline \multirow[t]{2}{*}{ Propolis } & A1 & 0.568 & 0.099 & 0.099 & 0.283 & 0.509 \\
\hline & A2 & 0.877 & 0.260 & 0.260 & 0.059 & 1 \\
\hline
\end{tabular}

\subsection{Estimated Risk to Consumers through Honey Consumption}

Estimated daily intake rates ranged between $0.5 \times 10^{-5}$ (intake of $\mathrm{Pb}$ through honey consumption from the agricultural area) and $9 \times 10^{-3}$ (intake of $\mathrm{Zn}$ through honey consumption from the industrial area). RfDs for investigated heavy metals are presented in Table 16. These values were below the limit values established by JECFA [50]. The HQ values ranged between $2.2 \times 10^{-5}$ ( $\mathrm{Mn}$ in the $\mathrm{A} 2$ site) and $4 \times 10^{-3}$ ( $\mathrm{Pb}$ in the A1 area). Thus, even if HQ values are lower than 1, the higher risks were registered for lead by consuming honey from the A1 area. 
Table 16. Estimated daily intake rates and hazard quotient of metals through honey consumption in A1 area (industrial activity) and A2 area (agricultural activity).

\begin{tabular}{cccccc}
\hline \multirow{2}{*}{ Contaminant } & \multicolumn{2}{c}{ EDI * } & \multicolumn{2}{c}{ HQ } & \multirow{2}{*}{$\begin{array}{c}\text { RfD [46] } \\
\text { (mg/kg bw) }\end{array}$} \\
\cline { 2 - 5 } & A1 & A2 & A1 & A2 & 0.001 \\
$\mathrm{Cd}$ & $1.75 \times 10^{-6}$ & $0.56 \times 10^{-6}$ & $1.75 \times 10^{-3}$ & $0.56 \times 10^{-3}$ & 0.5 \\
$\mathrm{Cu}$ & $7.60 \times 10^{-5}$ & $1.30 \times 10^{-5}$ & $1.52 \times 10^{-4}$ & $0.26 \times 10^{-4}$ & 1 \\
$\mathrm{Zn}$ & $9.00 \times 10^{-3}$ & $2.10 \times 10^{-3}$ & $1.50 \times 10^{-4}$ & $0.35 \times 10^{-4}$ & 1.5 \\
$\mathrm{Mn}$ & $6.40 \times 10^{-5}$ & $3.30 \times 10^{-5}$ & $4.30 \times 10^{-5}$ & $2.20 \times 10^{-5}$ & 0.0035 \\
$\mathrm{~Pb}$ & $1.40 \times 10^{-5}$ & $0.50 \times 10^{-5}$ & $4.00 \times 10^{-3}$ & $1.40 \times 10^{-3}$ & 0.02 \\
$\mathrm{Ni}$ & $3.00 \times 10^{-5}$ & $2.40 \times 10^{-5}$ & $2.40 \times 10^{-3}$ & $1.50 \times 10^{-3}$ & 0.14 \\
$\mathrm{Cr}$ & $6.60 \times 10^{-5}$ & $6.20 \times 10^{-5}$ & $4.70 \times 10^{-4}$ & $4.40 \times 10^{-4}$ & \\
\hline
\end{tabular}

$\overline{\mathrm{EDI}}=$ estimated daily intake $\left({ }^{*}\right.$ for an adult with $60 \mathrm{~kg}$ body weight). $\mathrm{HQ}=$ hazard quotient. RfD $=$ reference dose.

In most cases, heavy metal environment pollution means the contamination of honey, and this bee product could be an indicator for pollution, according to some authors. Therefore, beekeepers should be very careful when choosing A1 area for their hives, the more so because heavy metals (especially $\mathrm{Pb}, \mathrm{Hg}$ and $\mathrm{Cd}$ ) are known to be toxic to humans [65].

\section{Discussion}

Given the wide use of bee products, both for consumption and as active ingredients in various pharmaceutical formulations, rigorous quality control is required in order to avoid affecting the health of consumers. It is well known that these products are also marketed by small producers who often reach the market without subjecting the goods to a prior inspection. In the context of the increasing degree of pollution worldwide, it is imperative to assess the degree of contamination in bee products. The results of the study highlight the risk of contamination with various pollutants from the soil or other sources and even the accumulation of these toxic pollutants in quantities that can endanger the health of consumers.

For example, in all samples of honey and propolis collected from the A1 area (with intense industrial activity), lead values were recorded above the maximum allowed limits (the highest concentrations were identified in multifloral honey and propolis).

Even if the lead concentration is not so concerning, we must keep in mind, however, that lead can reach the human body from other sources as well. For example, it was demonstrated that some Asian traditional remedies and Ayurveda medications often contain plants, minerals or animal products with high lead concentrations [66].

In addition, Burden et al. (2019) conducted a study that proved that lead appeared to be appetizing at some concentrations and modified the bees' sensitivity to the rating of sucrose [67].

Increased copper and zinc levels have also been observed in large studies: for copper $0.45-2.43 \mathrm{mg} / \mathrm{kg}$ [58] and $18.89 \mathrm{mg} / \mathrm{kg}$ [68], and for zinc, $0.51-7.85 \mathrm{mg} / \mathrm{kg}$ [58] and $12.57 \mathrm{mg} / \mathrm{kg}$ [69]. Although zinc is an essential element, excessively bioaccumulated concentrations can cause several unwanted manifestations, such as nausea, diarrhea, vomiting, fever and lethargy.

The effect of environmental pollution on the quality and safety of various types of honey from beekeepers in mining areas known for bioaccumulations, especially of heavy metals, has been highlighted by studies in Romania that have identified high concentrations of cadmium, lead, copper and zinc [59,70].

Some studies have shown increased concentrations of pesticides in honey samples of Romanian origin [71].

Honey samples with pesticide concentrations above the maximum allowed level were also highlighted in a large study in which researchers analyzed 96 pesticide residues in 28 retail honey samples from Kenya and Ethiopia [72]. 


\title{
5. Conclusions
}

Honey and propolis remain two natural products that are still intensively studied and analyzed because of their various medicinal uses, given that they are able to replace antibiotic therapy in some situations. However, the degree of contamination with pollutants influences their therapeutic efficiency and consumers' health. That is why it is vital to analyze the quality of these products before making them available to consumers.

The heavy metal levels varied in honey and propolis samples depending on soil composition. An increased level of heavy metals was detected in samples collected from the industrial areas. Cadmium, lead, copper, zinc and the sum of DDT metabolites exceeded the maximum allowable levels in some honey samples, with differences between honey type. Therefore, the estimated daily intakes of $\mathrm{Cd}, \mathrm{Cu}, \mathrm{Zn}, \mathrm{Cr}, \mathrm{Pb}, \mathrm{Ni}$ and $\mathrm{Mn}$ through honey consumption were below the recommended daily dietary allowance for these elements. Moreover, the hazard quotient values for each metal were lower than 1 , showing that there was no health risk for consumers due to honey intake.

\begin{abstract}
Author Contributions: Conceptualization, M.M. and D.I.U.; methodology, E.O., M.N. and M.G.; software, M.G. and M.N.; validation, S.M.N., M.M. and D.I.U.; formal analysis, A.C.N.; investigation, M.M.; resources, A.C.N.; data curation, M.G.; writing-original draft preparation, D.I.U.; writingreview and editing, E.O.; visualization, S.M.N.; supervision, M.N.; project administration, M.M.; funding acquisition, A.C.N. and S.M.N. All authors have read and agreed to the published version of the manuscript.
\end{abstract}

Funding: This research received no external funding.

Institutional Review Board Statement: Not applicable.

Informed Consent Statement: Not applicable.

Data Availability Statement: Not applicable.

Conflicts of Interest: The authors declare no conflict of interest.

\section{References}

1. Samarghandian, S.; Farkhondeh, T.; Samini, F. Honey and Health: A Review of Recent Clinical Research. Pharmacogn. Res. 2017, 9, 121-127. [CrossRef]

2. Bell, S.G. The therapeutic use of honey. Neonatal Netw. 2007, 26, 247-251. [CrossRef]

3. Yaghoobi, R.; Kazerouni, A.; Kazerouni, O. Evidence for Clinical Use of Honey in Wound Healing as an Anti-bacterial, Antiinflammatory Anti-oxidant and Anti-viral Agent: A Review. Jundishapur J. Nat. Pharm. Prod. 2013, 8, 100-104. [CrossRef] [PubMed]

4. Eteraf-Oskouei, T.; Najafi, M. Traditional and modern uses of natural honey in human diseases: A review. Iran. J. Basic Med. Sci. 2013, 16, 731-742. [PubMed]

5. Arawwawala, M.; Hewageegana, S. Health Benefits and Traditional Uses of Honey: A Review. J. Apither. 2017, 2, 9. [CrossRef]

6. Ibrahim, N.I.; Wong, S.K.; Mohamed, I.N.; Mohamed, N.; Chin, K.Y.; Ima-Nirwana, S.; Shuid, A.N. Wound Healing Properties of Selected Natural Products. Int. J. Environ. Res. Public Health 2018, 15, 2360. [CrossRef] [PubMed]

7. Chaikham, P.; Kemsawasd, V.; Apichartsrangkoon, A. Effects of conventional on physicochemical properties and antioxidant capacity of floral honeys from Northern Thailand. Food Biosci. 2016, 15, 19-26. [CrossRef]

8. da Silva, P.M.; Gauche, C.; Gonzaga, L.V.; Costa, A.C.O.; Fett, R. Honey: Chemical composition, stability and authenticity. Food Chem. 2016, 196, 309-323. [CrossRef]

9. Escuredo, O.; Míguez, M.; Fernández-González, M.; Seijo, M.C. Nutritional value and antioxidant activity of honeys produced in a European Atlantic area. Food Chem. 2013, 138, 851-856. [CrossRef]

10. Aazza, S.; Lyoussi, B.; Antunes, D.; Miguel, M.G. Physico-chemical characterization and antioxidant activity of 17 commercial Moroccan honeys. Int. J. Food Nutr. 2014, 65, 449-457. [CrossRef]

11. Ranneh, Y.; Akim, A.M.; Hamid, H.A.; Khazaai, H.; Fadel, A.; Zakaria, Z.A.; Albujja, M.; Bakar, M.F.A. Honey and its nutritional and anti-inflammatory value. BMC Complement. Med. Ther. 2021, 21, 30. [CrossRef] [PubMed]

12. Hadagali, M.D.; Chua, L.S. The anti-inflammatory and wound healing properties of honey. Eur. Food Res. Technol. 2014, 239, 1003-1014. [CrossRef]

13. Bogdanov, S.; Jurendic, T.; Sieber, R.; Gallmann, P. Honey for nutrition and health: A review. Am. J. Coll. Nutr. 2008, 27, 677-689. [CrossRef] 
14. Mitu, M.A.; Cretu, E.A.; Novac, M.; Karampelas, O.; Nicoara, A.; Nitulescu, G.; Lupuleasa, D. The Flowing Characteristics of Some Composed Powders Containing Inclusion Complexes in Beta-Cyclodextrin. In Proceedings of the 17th Romanian National Congress of Pharmacy, Bucharest, Romania, 26-29 September 2018; pp. 129-133, ISBN 978-88-85813-28-1.

15. Paduraru, D.N.; Coman, F.; Ozon, E.A.; Gherghiceanu, F.; Andronic, O.; Ion, D.; Stanescu, M.; Bolocan, A. The use of nutritional supplement in romanian patients-Attitudes and beliefs. Farmacia 2019, 67, 1060-1065. [CrossRef]

16. Almasaudi, S. The antibacterial activities of honey. Saudi J. Biol. Sci. 2021, 28, 2188-2196. [CrossRef] [PubMed]

17. Mandal, M.D.; Mandal, S. Honey: Its medicinal property and antibacterial activity. Asian Pac. J. Trop. Biomed. 2011, 1, 154-160. [CrossRef]

18. Mullai, V.; Menon, T. Bactericidal activity of different types of honey against clinical and environmental isolates of Pseudomonas aeruginosa. J. Altern. Complement. Med. 2007, 13, 439-441. [CrossRef] [PubMed]

19. Oelschlaegel, S.; Gruner, M.; Wang, P.N.; Boettcher, A.; Koelling-Speer, I.; Speer, K. Classification and characterization of manuka honeys based on phenolic compounds and methylglyoxal. J. Agric. Food Chem. 2012, 60, 7229-7237. [CrossRef] [PubMed]

20. Afrin, S.; Gasparrini, M.; Forbes-Hernández, T.Y.; Cianciosi, D.; Reboredo-Rodriguez, P.; Manna, P.P.; Battino, M.; Giampieri, F. Protective effects of Manuka honey on LPS-treated RAW 264.7 macrophages. Part 1: Enhancement of cellular viability, regulation of cellular apoptosis and improvement of mitochondrial functionality. Food Chem. Toxicol. 2018, 121, 203-213. [CrossRef]

21. Cianciosi, D.; Forbes-Hernández, T.Y.; Afrin, S.; Gasparrini, M.; Reboredo-Rodriguez, P.; Manna, P.P.; Zhang, J.; Bravo Lamas, L.; Martínez Flórez, S.; Agudo Toyos, P.; et al. Phenolic Compounds in Honey and Their Associated Health Benefits: A Review. Molecules 2018, 23, 2322. [CrossRef]

22. Alvarez-Suarez, J.M.; Tulipani, S.; Romandini, S.; Bertoli, E.; Battino, M. Contribution of honey in nutrition and human health: A review. Med. J. Nutr. Metab. 2010, 3, 15-23. [CrossRef]

23. Warui, M.W.; Hansted, L.; Gikungu, M.; Mburu, J.; Kironchi, G.; Bosselmann, A.S. Characterization of Kenyan Honeys Based on Their Physicochemical Properties, Botanical and Geographical Origin. Int. J. Food Sci. 2019, 2932509. [CrossRef] [PubMed]

24. Viuda-Martos, M.; Navajas, Y.; Fernández-López, J.; Pérez-Álvarez, J.A. Functional properties of honey, propolis, and royal jelly. J. Food Sci. 2008, 73, R117-R124. [CrossRef] [PubMed]

25. Elnakady, Y.; Rushdi, A.; Franke, R.; Abutaha, N.; Ebaid, H.; Baabbad, M.; Omar, M.O.M.; Al Ghamdi, A.A. Characteristics, Chemical compositions and biological activities of propolis from Al-Bahah, Saudi Arabia. Sci. Rep. 2017, 7, 41453. [CrossRef]

26. Alanazi, S.; Alenzi, N.; Alenazi, F.; Tabassum, H.; Watson, D. Chemical characterization of Saudi propolis and its antiparasitic and anticancer properties. Sci. Rep. 2021, 11, 5390. [CrossRef]

27. Food and Agriculture Organization of the United Nations. Main Bee Diseases: Good Beekeeping Practices; Food and Agriculture Organization of the United Nations: Rome, Italy, 2018. Available online: https://www.fao.org/3/i9466en/I9466EN.pdf (accessed on 18 November 2021).

28. Best Management Practices for Hive Health a Guide for Beekeepers. Available online: https://honeybeehealthcoalition.org/ wpcontent/uploads/2019/01/HBHC_Hive_BMPs_v1.0_reduced.pdf (accessed on 25 November 2021).

29. Amulen, D.R.; Spanoghe, P.; Houbraken, M.; Tamale, A.; de Graaf, D.C.; Cross, P.; Smagghe, G. Environmental contaminants of honeybee products in Uganda detected using LC-MS/MS and GC-ECD. PLoS ONE 2017, 12, e0178546. [CrossRef]

30. López, S.H.; Lozano, A.; Sosa, A.; Hernando, M.D.; Fernández-Alba, A.R. Screening of pesticide residues in honeybee wax comb by LC-ESI-MS/MS. A pilot study. Chemosphere 2016, 163, 44-53. [CrossRef]

31. Girotti, S.; Ghini, S.; Ferri, E.; Bolelli, L.; Colombo, R.; Serra, G.; Porrini, C.; Sangiorgi, S. Bioindicators and biomonitoring: Honeybees and hive products as pollution impact assessment tools for the Mediterranean area. Euro-Mediterr. J. Environ. Integr. 2020, 5, 62. [CrossRef]

32. Mititelu, M.; Moroşan, E.; Neacsu, S.M.; Ioniţă, E.I. Research regarding the pollution degree from romanian Black Sea coast. Farmacia 2018, 66, 1059-1063. [CrossRef]

33. Mititelu, M.; Ghica, M.; Ionita, A.C.; Moroşan, E. The influence of heavy metals contamination in soil on the composition of some wild edible mushrooms. Farmacia 2019, 67, 398-404. [CrossRef]

34. Jaishankar, M.; Tseten, T.; Anbalagan, N.; Mathew, B.B.; Beeregowda, K.N. Toxicity, Mechanism and health effects of some heavy metals. Interdiscip. Toxicol. 2014, 7, 60-72. [CrossRef]

35. Ali, H.; Khan, E.; Ilahi, I. Environmental Chemistry and Ecotoxicology of Hazardous Heavy Metals: Environmental Persistence, Toxicity, and Bioaccumulation. J. Chem. 2019, 6730305. [CrossRef]

36. Ali, H.; Khan, E. Environmental chemistry in the twenty-first century. Environ. Chem. Lett. 2017, 15, 329-346. [CrossRef]

37. Raymond, A.W.; Felix, E.O. Heavy Metals in Contaminated Soils: A Review of Sources, Chemistry, Risks and Best Available Strategies for Remediation. Int. Sch. Res. Not. 2011, 402647. [CrossRef]

38. Damalas, C.A.; Koutroubas, S.D. Farmers' Exposure to Pesticides: Toxicity Types and Ways of Prevention. Toxics 2016, 4, 1. [CrossRef] [PubMed]

39. Nedelescu, M.; Baconi, D.; Neagoe, A.; Iordache, V.; Stan, M.; Ciobanu, A.M.; Vardavas, A.I.; Vinceti, M.; Tsatsakis, A.M. Environmental metal contamination and health impact assessment in two industrial regions of Romania. Sci. Total Environ. 2017, 580, 984-995. [CrossRef]

40. Bao, L.J.; Wei, Y.L.; Yao, Y.; Ruan, Q.Q.; Zeng, E.Y. Global trends of research on emerging contaminants in the environment and humans: A literature assimilation. Environ. Sci. Pollut. Res. 2015, 22, 1635-1643. [CrossRef] 
41. Gavrilescu, M.; Demnerová, K.; Aamand, J.; Agathos, S.; Fava, F. Emerging pollutants in the environment: Present and future challenges in biomonitoring, ecological risks and bioremediation. New Biotechnol. 2015, 32, 147-156. [CrossRef] [PubMed]

42. Moser, F.; Dondi, F. Environmental protection between chemical practice and applied ethics: A critical review. Toxicol. Environ. Chem. 2015, 6, 100-110. [CrossRef]

43. Ekström, G.; Ekbom, B. Pest control in agro-ecosystems: An ecological approach. Crit. Rev. Plant Sci. 2011, 30, 74-94. [CrossRef]

44. Ioniţă, A.C.; Ghica, M.; Moroşan, E.; Nicolescu, F.; Mititelu, M. In vitro effects of some synthesized aminoacetanilide n'-substituted on human leukocytes separated from peripheral blood. Farmacia 2019, 67, 684-690. [CrossRef]

45. Romanian Ministry of Agriculture and Rural Development. Situation of Honey Sector in Romania 2014-2016. Available online: https:/ / www.madr.ro/cotatii-bursiere/tag/apicultura.html (accessed on 25 November 2021).

46. IndexBox. EU-Honey-Market Analysis, Forecast, Size, Trends and Insights Update: COVID-19. 2021. Available online: https: //www.indexbox.io/store/eu-honey-market-analysis-forecast-size-trends-and-insights/ (accessed on 18 November 2021).

47. Năstăsescu, V.; Mititelu, M.; Goumenou, M.; Docea, A.O.; Renieri, E.; Udeanu, D.I.; Oprea, E.; Arsene, A.L.; Dinu-Pîrvu, C.E.; Ghica, M. Heavy metal and pesticide levels in dairy products: Evaluation of human health risk. Food Chem. Toxicol. 2020, 146, 111844. [CrossRef] [PubMed]

48. Wang, W.X. Bioaccumulation and Biomonitoring. In Marine Ecotoxicology; Academic Press: Cambridge, MA, USA, 2016; pp. 99-119. [CrossRef]

49. Juan-Borras, M.; Domenech, E.; Esriche, I. Mixture-risk-assessment of pesticide residues in retail polyfloral honey. Food Control 2016, 67, 127-134. [CrossRef]

50. World Health Organization (WHO) and Food and Agriculture Organization (FAO). Guidelines for the Safe Use of Wastewater and Food Stuff. Report of the Joint WHO/FAO Volume 2 No. 1; WHO: Geneva, Switzerland, 2013. Available online: https: //www.who.int/water_sanitation_health/wastewater/wwuvol2intro.pdf (accessed on 25 November 2021).

51. Joint FAO/WHO Expert Committee on Food Additives (JECFA)-Guidelines for the Simple Evaluation of Dietary Exposure to Food Additives. CAC/GL 3-1989, Revizuit 2014. Available online: http://www.codexalimentarius.org (accessed on 18 November 2021).

52. Mair, P.; Wilcox, R. Robust statistical methods in R using the WRS2 package. Behav. Res. Methods 2019, 52, 464-488. [CrossRef]

53. Albeanu, G.; Ghica, M.; Popentiu-Vladicescu, F. On using bootstrap scenario-generation for multi-period stochastic programming applications. Int. J. Comput. Commun. Control 2008, 3, 156-161.

54. Romanian Ministry of Waters, Forests and Environmental Protection Order No. 765/1997 for the Approval of the Settlement Regarding Environment Pollution Assessment; Official Monitor, Part I, nr.303 bis; Monitorul Oficial R.A.: Bucharest, Romania, 1997; Printed by Monitorul Oficial. (In Romanian)

55. Commission Regulation (EC) No 1881/2006 of 19 December 2006 setting maximum levels for certain contaminants in foodstuffs. Off. J. Eur. Union 2006, L364/5-L364/24. Available online: https:/ / eur-lex.europa.eu/LexUriServ /LexUriServ.do?uri=OJ:L:2006: 364:0005:0024:EN:PDF (accessed on 25 November 2021).

56. Codex Alimentarius. Codex Alimentarius Standard for Honey 12-1981. Revised Codex Standard for Honey. Standards and Standard Methods (Vol. 11). 2001. Available online: http:/ / www.codexalimentarius.net (accessed on 18 November 2021).

57. Council Directive 2001/110/EC Relating to Honey. EU Off. J. 2002, L10, 47-52. Available online: https://www.fsai.ie/ uploadedFiles/Consol_Dir2001_110.pdf (accessed on 25 November 2021).

58. Roman, A.; Madras-Majewska, B.; Popiela, E. Comparative study of selected toxic elements in propolis and honey. J. Apic. Sci. 2011, 55, 97-106.

59. Bartha, S.; Taut, I.; Goji, G.; Vlad, I.A.; Dinulică, F. Heavy Metal Content in PolyfloralHoney and Potential Health Risk. A Case Study of Copșa Mică, Romania. Int. J. Environ. Res. Public Health 2020, 17, 1507. [CrossRef]

60. Altunatmazi, S.S.; Tarhan, D.; Aksu, F.; Ozsobaci, N.P.; Mehmet, E.O.; Barutçu, U.B. Levels of Chromium, Copper, Iron, Magnesium, Manganese, Selenium, Zinc, Cadmium, Lead and Aluminium of honey varieties produced in Turkey. Food Sci. Technol. 2019, 39, 392-397. [CrossRef]

61. Commission Regulation (EC) No. 396/2005 of the European Parliament, of the Council of 23 February 2005 on Maximum Residue Levels of Pesticides in or on Food, Feed of Plant, Animal Origin. EU Off. J. 2005, L70, 1-16.

62. Tomczyk, M.; Zagula, G.; Puchalski, C.; Dzugan, M. Transfer of some toxic metals from soil to honey depending on bee habitat conditions. Acta Univ. Cibiniensis Ser. E Food Technol. 2020, 24, 49-59. [CrossRef]

63. Chiesa, L.M.; Labella, G.F.; Giorgi, A.; Panseri, S.; Pavlovic, R.; Bonacci, S.; Arioli, F. The occurrence of pesticides and persistent organic pollutants in Italian organic honeys from different productive areas in relation to potential environmental pollution. Chemosphere 2016, 154, 482-490. [CrossRef] [PubMed]

64. Goretti, E.; Pallottini, M.; Rossi, R.; La Porta, G.; Gardi, T.; Cenci Goga, B.T.; Elia, A.C.; Galletti, M.; Moroni, B.; Petroselli, C.; et al. Heavy metal bioaccumulation in honey bee matrix, an indicator to assess the contamination level in terrestrial environments. Environ. Pollut. 2020, 256, 113388. [CrossRef] [PubMed]

65. Moujanni, A.; Terrab, A.; Eddoha, R.; Nasser, B.; Benbachir, M.; Tannaoui, M.; Zouaoui, A.; Essamadi, A.K. Quantification of heavy metals and pesticides residues in labeled Moroccan Euphorbia resinifera honey from Tadla-Azilal. JMES 2017, 8, 1826-1836.

66. Potential for Human Exposure. Available online: https:/ / www.atsdr.cdc.gov/ToxProfiles/tp13-c5.pdf (accessed on 25 November 2021).

67. Burden, C.M.; Morgan, M.O.; Hladun, K.R.; Amdam, G.V.; Trumble, J.J.; Smith, B.H. Acute sublethal exposure to toxic heavy metals alters honey bee (Apis mellifera) feeding behavior. Sci. Rep. 2019, 9, 4253. [CrossRef] 
68. Ciobanu, O.; Rădulescu, H. Monitoring of Heavy Metals residues in honey. Res. J. Agric. Sci. 2016, 48, 13.

69. Dżugan, M.; Zaguła, G.; Wesołowska, M.; Sowa, P.; Puchalski, C.Z. Levels of toxic and essential metals in varietal honeys from Podkarpacie. J. Elem. 2017, 22, 1039-1048. [CrossRef]

70. Bratu, I.; Georgescu, C. Chemical contamination of bee honey-identifying sensor of the environment pollution. J. Cent. Eur. Agric. 2005, 6, 95-98.

71. Simedru, D.; Becze, A.; Cadar, O.; Roman, M.; Tanaselia, C. Polycyclic Aromatic Hydrocarbons and heavy metals contamination in honey from Cluj County, Romania. Agricultura 2017, 1-2, 101-102.

72. Irungu, J.; Raina, S.; Torto, B. Determination of pesticide residues in honey: A preliminary study from two of Africa's largest honey producers. Food Contam. 2016, 3, 14. [CrossRef] 